\title{
MOTIVAÇÕES PARA UMA REVISITAÇÃO DE ÁFRICA: CONTRIBUTO NO FEMININO PARA A LITERATURA (PÓS-)COLONIAL
}

Sandra Isabel Marques

Resumo: No campo literário, a forma como homens e mulheres escrevem foi provocando várias reflexões seminais cuja base de argumentação recai nas respetivas escolhas a nível das temáticas, perspetivas, personagens ou cenários. Dessas escolhas emergem vozes distintas que se encontram em contraponto em múltiplos aspetos. No entanto, essas vozes não têm de ser anuladas ou categorizadas como melhores ou piores, superiores ou inferiores, em virtude do sexo dos respetivos autores. Trata-se de discursos polifónicos e independentes, que coexistem no sistema literário e que devem encontrar harmonia na sua complementaridade. Também na literatura (pós-)colonial é preciso reconhecer e respeitar o contributo da mulher escritora através do estudo das suas obras e das temáticas que elegem, os quais preenchem os vazios deixados pela versão oficial da História.

Interessou, então, através de um corpus escrito por mulheres, que viveram, elas próprias, experiências (pós-)coloniais, tornar mais plurais e diversas as perspetivas (pós)coloniais, comummente dominadas pela voz literária masculina, considerando processos de memória e esquecimento. Interessou não só perceber o porquê do pacto tácito de silêncio em torno da queda do império português e as motivações que estiveram na base do esquecimento da figura do retornado, como também se pretendeu clarificar os seus processos de acolhimento e de receção e desconstruir os discursos anticolonialistas em torno da sua figura. A questão da objetificação da mulher e o menosprezo pelos seus direitos foram também abordados.

Palavras-chave: (Pós-)colonial. Mulheres. Retorno. África. Retornados.

Abstract: The way women and men write has always been the object of several interesting discussions namely the different themes, perspectives, characters or settings chosen. There are different voices that arise from these selections, which are contrapuntal in several aspects. Nevertheless, those voices do not have to be annulled or categorized as being better or worse, superior or inferior, according to 
the sex of the writers. They are polyphonic and independent speeches, which must coexist in the literary system and should be harmonious in their complementarity. Therefore, the (post)colonial literature also has to acknowledge and respect the contribution of the women writer through the study of their writings and themes selected, which fill in the void left out by the official version of the History.

Thus, through a corpus of women writers who had lived, themselves, (post)colonial experiences, there was an interest to make the (post) colonial perspectives, usually dominated by the male literary voice, more plural and diverse, taking the processes of memory and forgetfulness into account. It was considered important to understand the reasons for the tacit agreement of silence on the fall of the Portuguese empire and what motivated the forgetting of those who had returned from the colonies. It was also an aim to clarify their process of reception as well as the reasons why there were anti-colonialist speeches about them. The perception of the woman as an object and the disregard of their rights were also a matter of attention.

Keywords: (Post)colonial. Women. Return. Africa. Returners.

No campo literário, a forma como homens e mulheres escrevem foi provocando várias reflexões seminais como aquelas - incontornáveis - de Virginia Woolf em $A$ Room of One's Own (1929) e Three Guineas (1938) ou de Simone de Beauvoir em The Second Sex (1949), e outras tantas discussões cuja base de argumentação recai nas respetivas escolhas a nível das temáticas, perspetivas, personagens ou cenários. Dessas escolhas emergem vozes distintas que se encontram em contraponto em múltiplos aspetos. No entanto, defendese aqui que o facto de estarem em contraponto não significa, de todo, que alguma dessas vozes tenha de ser anulada ou categorizada como melhor ou pior, superior ou 
inferior, em virtude do sexo dos respetivos autores. Tratase de discursos polifónicos e independentes, que coexistem no sistema literário e que devem encontrar harmonia na sua complementaridade. Para isso, é preciso reconhecer e respeitar o contributo da mulher escritora também no plano literário de modo a possibilitar uma abordagem e um conhecimento mais plural. Todavia, a produção literária de autoria feminina não tem tido a mesma visibilidade que a dos seus homólogos masculinos, como mostra Chatarina Edfeld em Uma história na História: Representações da autoria feminina na História da Literatura Portuguesa do século $X X$, de 2006. No decorrer da sua investigação, a autora procura mostrar que o sexo dos autores subjaz à categorização, organização e valorização da produção literária considerada nas obras relativas à história da literatura portuguesa, sendo que o género feminino é continuamente marginalizado, não por razões estéticas, mas por razões políticas e de tradição. O estudo pretende ainda demonstrar que a discriminação das mulheres não termina na ausência da sua representatividade, pois os critérios para a inclusão de obras de autoria feminina são dúbios e distintos daqueles que se aplicam aos homens escritores. Essa constatação leva a concluir que a literatura produzida por mulheres é ainda encarada como uma experiência particular, sobre mulheres e 
para mulheres, enquanto os homens escritores produzem obras que traduzem experiências universais. À luz desta perspetiva, o reconhecimento da sua função de escritora não é distinto do seu papel de "mulher" e a avaliação dos seus textos é feita com base em "parâmetros que estipulam a construção do papel feminino na sociedade e não dos que estão em voga para os homens escritores" (EDFELDT, 2006, p. 27).

Um dos efeitos desta atuação traduz-se na redução da visibilidade da mulher escritora e na diminuição da sua voz. No entender da autora, tal silenciamento da voz feminina assume contornos muito graves no que respeita à preservação da memória coletiva nacional. A par da falsa assunção da inexistência - ou quase inexistência de mulheres escritoras no passado, perdem-se também narrativas literárias com posicionamentos e perspetivas plurais, contributos incontornáveis para um conhecimento mais rico e alargado.

Impõe-se acrescentar que a desvalorização da voz da mulher e o desmerecimento que as suas obras colhem, ainda hoje, ao nível da receção assentam em critérios parciais, preconceituosos e desfasados de uma realidade que se deve pautar pela igualdade e pela equidade. 
Nesse sentido, defende-se que as formas de acesso, promoção e divulgação das suas obras deve ser igual, independentemente do género, e aos leitores competirá eleger as vozes com as quais se identificam sem estarem, à partida, condicionados pela oferta e pela credibilidade que uma determinada temática terá se for tratada por um escritor ou por uma escritora.

Assim, o facto de ainda persistirem tantas perguntas sem resposta justificam o cuidado, no campo da literatura (pós-)colonial, a que se atente numa escrita de autoria feminina, cujo ângulo foi sempre menorizado. Em defesa da qualidade das suas obras e do seu olhar contrastivo ou complementar, revela-se crucial reconhecer o contributo da voz feminina na abordagem de temáticas comummente dominadas pela voz e pela perspetiva masculinas, num tempo anterior e posterior às independências, até pela possibilidade de poder eventualmente trabalhar outros objetos de atenção.

Na realidade, a invisibilidade e o menosprezo sentidos pelas mulheres na área da Literatura não é distinta da que elas foram experienciando no espaço social. No que concerne, por exemplo, a guerra colonial, embora o papel da mulher portuguesa tenha sido imprescindível, a verdade 
é que foi estranhamente secundarizado e subjugado pelas ações e heroicidade masculinas. O investigador de História Contemporânea de Portugal, Carlos de Matos Gomes, define os anos sessenta como marcador temporal do ponto de viragem para as mulheres portuguesas. Refém dos deveres tradicionais de mãe, mulher e esposa submissa, que o poder salazarista apoiava, a mulher, em consequência da guerra colonial, começa gradualmente a assumir "o papel de cidadã, de indivíduo com direitos perante a sociedade" (GOMES, 2015, p. 10-11). Forçada a ser mais ativa, a mulher pôde ir além do seu papel tradicional e ajudar o país a enfrentar um conflito que durou anos. Segundo Sofia Branco, a guerra colonial e a emigração contribuíram para que as mulheres desbravassem caminhos rumo à sua emancipação, levando-as a ocupar "lugares do mercado de trabalho deixados vagos pela mobilização e pela emigração, a tomarem as rédeas das suas vidas, sozinhas, a intervirem mais no espaço público" (2015, p. 21-22). Com efeito, a guerra não se confinou apenas à esfera masculina. Embora só um pequeno número de enfermeiras paraquedistas tenha sido mobilizado para combater na guerra, as mulheres que permaneceram no território viram-se obrigadas a travar outras lutas, ao assumirem um papel ativo na gestão doméstica e no sustento da família. Perante esse conflito 
bélico, nos então designados territórios ultramarinos, as mulheres não ficaram inertes e envolveram-se quer apoiando o esforço de guerra quer opondo-se ao regime. Muitas, ainda, acompanharam os maridos e tiveram acesso a uma outra perspetiva da guerra que escapou ao olhar masculino. Todavia, apesar de o seu papel ter sido importante na gestão informal do país e nas retaguardas do conflito, Sofia Branco relembra que, à semelhança de outros acontecimentos históricos marcantes, a História tem privilegiado a voz masculina para seu narrador, não sendo, por isso, uma exceção aquilo que diz respeito à guerra colonial.

A importância de se atentar numa voz feminina também é defendida por Isabel Allegro de Magalhães, em O Sexo dos Textos, onde conclui que "a escrita feminina [...] tem contribuído [...] para dar voz à experiência das mulheres e ao inconsciente feminino, deixados mudos pela cultura (masculina) dominante" (1995, p. 10-11). No seu entender, as autoras estão mais atentas às situações de injustiça e de sofrimento de ambas as partes envolvidas, portugueses e indígenas e, comparativamente, tendem a ser mais críticas nas questões que envolvem as circunstâncias de guerra. Esta diferença em termos narrativos é desde logo 
justificada por Isabel Allegro de Magalhães pela participação distinta de homens e mulheres no cenário de guerra, mas a autora também aponta o facto de as mulheres terem que desenvolver, ao longo dos anos, uma perceção e atenção que as fez reparar em quem não tinha normalmente voz, pertencentes a classes sociais inferiores, mas detentoras de uma grande dimensão humana e cuja presença na narrativa não depende das personagens principais.

Não obstante, mais importante que reforçar uma alegada diferença entre a escrita de homens e a escrita de mulheres, até porque como bem lembram Ana Luísa Amaral e Maria Irene Santos em Sobre a escrita feminina, esta "poderá não ser a perspectiva mais produtiva" (1997, p. 5), a tónica deve residir na vantagem em ter acesso à diversidade de umas vozes e de outras. De facto, de acordo com Isabel Gould, nos últimos anos, o novo romance português de revisitação africana tem tido uma "preferência nítida pelas temáticas da família e da mulher colonial [...] que, deste modo, se propõe examinar a identidade do Portugal colonial e pós-imperial" (2007, p. 65). Independentemente do sexo dos respetivos autores, tais romances incluem temáticas associadas, no passado, ao género feminino.

Em relação à inclusão das vozes marginais, os estudos pós-coloniais, na perspetiva de Boaventura de Sousa Santos 
têm um papel preponderante, porque permitem entrelaçar o discurso sincopado da elite com o discurso abafado daqueles que não tiveram voz: "o papel dos estudos póscoloniais pode ser decisivo no sentido de ampliar essa 'consciência nacional', preenchendo-a com vozes que as elites nacionais (para já não falar do poder colonial) esqueceram ou excluíram" (2001, p. 35).

"Dos fracos não reza a história" e a experiência traumática pós-colonial, nomeadamente a dos retornados, só muito recentemente revisitada a partir das obras de Aida Gomes, Isabela Figueiredo e Dulce Maria Cardoso, ficou reduzida a um momento da História em que, como refere Eduardo Lourenço, "os Portugueses estiveram ausentes de si mesmos" (2013, p. 48). De facto, esta suspensão coletiva da consciência perdurou também ao nível da própria narrativização da história, o que é bastante significativo. Em 1994, vinte anos depois do 25 de Abril, o historiador José Medeiros Ferreira escrevia a propósito da dificuldade em encontrar estudos sobre a descolonização por ser, na sua opinião, um "domínio ainda sacralizado da história nacional" (1994, p. 53) e realçava o pouco interesse analítico que a questão despertara na comunidade científica. 
Uma possível explicação para este desinteresse, quer da comunidade científica quer da generalidade dos portugueses, que se traduziu em omissão e na substituição de uma "mitologia de império por uma mitologia de descolonização" (Reis, 2017, p. 101), poderá ser o facto de o drama dos retornados, a par da violenta Guerra Colonial, contrastar com a ideia de exemplaridade perpetuada pelo regime salazarista, com a Revolução pacífica de Abril e com a jovem democracia que, ao invés de denunciar e emendar os erros do passado, antes encontrara, na opinião de Eduardo Lourenço, "uma solução à portuguesa, igualmente exemplar da descolonização" (2013, p. 49). Assim, o país, apesar de ter perdido o seu império, agia como se a diminuição dos limites geográficos, que implicou também uma subtração no ego português, não pressupusesse qualquer reação; como se a democracia implicasse a acostumada conformação com as circunstâncias adversas e não uma radical mudança dos resignados padrões comportamentais.

É fundamental perceber que o regime salazarista através do silêncio, da censura e do controlo da informação, fomentou um profundo desconhecimento daquilo a que Eduardo Lourenço chama de "o drama africano" (2016, p. 294). Com efeito, a manipulação da informação permitiu 
que o "Estado Novo prolonga[sse] o retrato da harmoniosa nação pluricontinental até ao limite" (ANTUNES, 2015, p. 46). O que causa estranheza nesta matéria é que, já sob regime democrático, tendo acesso à informação e podendo ter uma atitude diferenciadora, os portugueses continuaram a escolher ignorar o problema. Eduardo Lourenço recorda que "após 76", houve escritores como Lobo Antunes, Lídia Jorge ou Fernando Dacosta que, através das suas obras, pretenderam invadir o "imaginário nacional" com esta temática, mas lamenta que nem "um só eco" deste traumatismo nacional tenha merecido ser registado. Por conseguinte, conclui que, dos tempos coloniais, "não ficou mais que o silencioso e silenciado murmúrio amargurado e ressentido dos chamados - estranha coisa - 'os retornados'" (2016, p. 294), ou melhor dizendo, destroços, em forma de gente, de um império decadente que não os pôde renegar, mas que se apressou a sonegar a sua voz.

Inversamente, a partir das suas próprias experiências e fazendo uso de figurações textuais distintas, as obras Os Pretos de Pousaflores, de Aida Gomes, O Retorno, de Dulce Maria Cardoso e Caderno de Memórias Coloniais, de Isabela Figueiredo, para além de fazerem regressar a figura do "retornado" à perceção pública, trouxeram 
outros ângulos do processo de descolonização que contribuíram para um conhecimento mais amplo acerca desta problemática. Da leitura das obras sobressaem os sentimentos de desintegração e de desenquadramento daqueles que, rotulados de "retornados", nunca tinham pensado regressar às suas origens ou de tantos outros que nunca tinham sequer estado em Portugal. Tornaram-se igualmente percetíveis os comportamentos discriminatórios e racistas dos portugueses que encaravam os retornados como usurpadores de casas e empregos face à conjuntura de desaceleração económica e à crise política e social que afetava Portugal, no pós-25 de abril de 1974, e que deram origem a memórias traumáticas que contrastam com os discursos edulcorados acerca desta problemática.

Atinente à disseminação das ideias de sucesso da integração dos retornados refira-se, por exemplo, o estudo académico efetuado pelo sociólogo Rui Pena Pires para quem o processo de integração dos retornados foi "um caso de assimilação" (2003, p. 189). O autor justifica essa conclusão pelo facto de estes emigrantes de primeira geração terem regressado para locais onde tinham as suas raízes e assim mais facilmente conseguirem emprego, apoio familiar e institucional. Além disso, defende que 
no quadro de alterações sociais que se fazia sentir à época, em Portugal, o repatriamento terá sido positivo por contribuir para o rejuvenescimento da população, aumentar o número de mão-de-obra qualificada e propiciar a diversidade cultural.

Em 2006, Almeida Santos, responsável político envolvido no processo de descolonização, num subcapítulo do seu livro de memórias, intitulado "O milagre da amizade e da solidariedade", não poupou elogios à forma abnegada como o país e os portugueses receberam estes deslocados:

A instituição familiar funcionou em pleno: os familiares de cá foram capazes de se sacrificar e acolher sem egoísmo os familiares que lhes bateram à porta. Abriuse a porta, abriu-se o coração. [...]

O sentimento da amizade funcionou também. Amigos acolheram e ajudaram amigos. [...]

E a raiz universalista e franciscana de um povo que viajou por todos os azimutes, falou todas as línguas, amou em todas as camas e rezou em todos os templos, repeliu a inveja, o espírito de competição, a tentação repulsiva do intruso.

Foi bonito! Ninguém achou que o Estado ajudou de mais quem chegava, em detrimento de quem já estava. Ninguém. $E$ as instâncias decisórias [...] nunca tiveram de vencer outras dificuldades que não a 
escassez de meios para a magnitude da tragédia. Incompreensões, xenofobias, egoísmos, isso nunca! (2006, p. 549)

No mesmo enquadramento de sucesso, refira-se, por último, o breve segmento dedicado a esta temática pelo cientista social António Barreto no seu documentário Portugal, Um Retrato Social - Nós e os outros, no qual a situação dramática dos retornados é minimizada e resumida à apresentação sumária de um quadro positivo, como se tudo se tivesse passado de forma incólume e na mais apática resignação das partes envolvidas:

Com a descolonização, em 1975, cerca de 600 mil portugueses [...] vêm para Portugal. Apesar das dificuldades, estas pessoas integraram-se. Depois de terem perdido terra, casa e emprego tiveram de recomeçar a vida. [...] Foram ajudadas por programas especiais do governo. Não se conhecem outros casos de um tão grande número de pessoas se ter misturado tão rapidamente e sem conflitos. (2011, 25min 02seg)

Ora, de acordo com esta sintética e mitificadora narrativa do processo de vinda e integração dos "retornados" para Portugal, em 1975-76, tudo se teria passado sem quaisquer problemas. Sobre este "milagre" de aceitação plena, de completa harmonia, de total ausência de problemas se pode concluir que, décadas depois, ou porque ainda importava 
manter esta ideia ou porque realmente se quis acreditar no "milagre", certo é que a distância temporal não alterara a amnésia e a inércia que caracterizaram a sociedade do pós25 de Abril e o silêncio sobre questões que, não tendo sido, à época, problemas para não ter de se arranjar soluções, são enunciadas sob essa ótica pelas autoras antes nomeadas, que sofreram com a deslocação e experienciaram a receção e acolhimento dos portugueses.

Recorrendo às suas vivências, as autoras saem deste alinhamento e são a voz e o eco daqueles para quem o processo de descolonização não foi um sucesso; por isso, as suas memórias não são tão positivas ou indistintas, antes se fazem de contornos precisos, de quem, quase quarenta anos depois, sente ser necessário repor a experiência dos "retornados" no palco da discussão pública e da representação da História de Portugal contemporâneo. De facto, o embelezamento dos factos ou a superficialidade com que foram tratados, presente em representações que, no entender de Mário Artur Machaqueiro, "hoje sabemos pertencer ao domínio das ilusões e da mistificação" culminou no quase esquecimento da "figura ominosa do 'retornado' na percepção pública" (2017, p. 228), como também o refere Stephen C. Lubkemann, autor de um dos raros estudos dedicados ao retorno. 
De salientar que os sentimentos que a população nutria por este nicho populacional, e que concorreram para a dificuldade da sua integração, já eram antes evidentes no modo como eram encarados por terem emigrado para África. Na verdade, quem partia para África não era considerado emigrante uma vez que iria para um território que fazia parte da mesma pátria. Assim, embora grande parte dos retornados estivesse a regressar ao seu local de origem, a verdade é que não foram encarados nem rececionados como outros emigrantes vindos de França, de Alemanha, da Suíça, da Venezuela ou dos Estados Unidos da América. A diferença entre eles, como explica Lubkemann, prendese com o nível de empenho e de participação que estes emigrantes mantinham com a sua comunidade de origem, ao fazer visitas periódicas, nas férias, ao enviar dinheiro ou ao investir em terrenos e construir casas no país com o intuito de um dia a ele regressar. Pelo contrário, aqueles que decidiram ir para as colónias africanas, aceitando os incentivos governamentais, tinham escolhido um destino de emigração de fixação, o que significava quebrar os laços com a família e com a comunidade em busca de riqueza para si próprios e não antever voltar ou contribuir financeiramente para a riqueza do país. Por conseguinte, no entender das populações rurais de origem destes emigrantes, era até 
questionável receberem formas de ajuda uma vez que quiseram, por vontade própria, abandonar as suas raízes (LUBKEMANN, 2003).

No corpus literário eleito, são vários os exemplos que atestam este ambiente de receção e integração adversos e que contrapõem o discurso aureolado de Almeida Santos e as demais teses de bom acolhimento dos retornados. 0 romance $O$ Retorno dá voz a muitas das reações suscitadas pela vinda dos portugueses que abandonaram, de moto próprio ou forçados, as antigas colónias portuguesas em África, para virem instalar-se em Portugal. Aliás, dessa disponibilidade e apoio só se enuncia um caso, o do Sr. Flávio, do quarto 211. A família de Rui, personagem principal, que em todas as cartas manifestava interesse, carinho e saudades, cinge o seu apoio à redação de uma outra carta, na qual lamenta os acontecimentos, mas deixa-os entregues à sua sorte. Trata-se, por isso, de um apoio moral hipócrita e à distância, cujo grande objetivo é evitar dispêndios financeiros, como bem o percebe Rui, que revoltado, não deseja voltar a vê-los.

Através de Rui, mencionam-se as ideias que circulavam em relação aos retornados, um grupo de exploradores que oprimira os negros e que agora, instalados em hotéis de 
cinco estrelas, beneficiava igualmente de serventia. Além disso, a sua presença, nunca bem-vinda, representava uma ameaça relativamente aos poucos empregos que existiam e à preservação dos imóveis e da pátria. Os retornados eram também responsabilizados pela Guerra Colonial que, desde o início da década de 60, obrigara milhares de jovens a partir de Portugal para combater em África, o que favorecia o distanciamento nas relações (CARDOSO, 2014).

Pela voz de Rui, Dulce Maria Cardoso desconstrói as representações que se enraizaram relativamente a este período e a este grupo de pessoas. Foram várias as questões que, pela sua falta de rigor e factualidade, a incomodaram e a impeliram a escrever O Retorno. O IARN, Instituto de Apoio ao Retorno Nacional, e a forma como os portugueses viram a sua ajuda aos "retornados", mais concretamente a sua instalação em hotéis, é apenas uma delas que também esperava poder clarificar. A História atribui a este organismo, criado após o 25 de Abril, um papel determinante na resolução dos problemas dos "retornados", como confirma o historiador José Medeiros Ferreira. Foram vários os benefícios concedidos por este organismo, desde a "recepção, acolhimento e viagens pagas [...], alojamento gratuito [...]; subsídio de desemprego, abono de família, 
assistência médica, medicamentosa e hospitalar" (1994, p. 89) entre outros.

Em O Retorno, a omnipresença e a dependência do IARN são inegáveis. Qualquer problema encontraria solução através deste organismo, o que leva Rui a compará-lo a uma espécie de deus, tal é a sua generosidade:

Sem o pai não sabíamos o que fazer mas as outras famílias também não sabiam, e agora, e agora, perguntavam. Em quase todas as respostas uma palavra que nunca tínhamos ouvido, o IARN, o IARN, o IARN.

O IARN paga as viagens para terra, o IARN põe-nos em hotéis, o IARN, paga o transporte para os hotéis, o IARN dános comida, o IARN dá-nos dinheiro, o IARN ajuda-nos, o IARN aconselha-nos, o IARN pode informar-nos. Nunca tinha ouvido tantas vezes uma palavra, o IARN parecia mais importante e mais generoso do que deus. Explicaram-nos, IARN quer dizer Instituto de Apoio ao Retorno dos Nacionais. (CARDOSO, 2014, p. 77)

Porém, ao construir uma representação ficcional apoiada num conhecimento direto dos acontecimentos, resulta evidente, a partir da leitura da obra de Dulce Maria Cardoso, a oportunidade de negócio que o IARN, representou para muitos empresários, nomeadamente da indústria hoteleira. A solidariedade pelos retornados e o seu acolhimento 
não terão passado de uma forma de evitar a situação de falência a que muitos estariam destinados devido à instabilidade política do país. José Medeiros Ferreira ratifica esta representação dos acontecimentos. Efetivamente, a indústria turística estava a atravessar um período de crise e a instalação em hotéis foi uma "solução precária que havia salvo de dificuldades muitas unidades hoteleiras num mau ano para a indústria turística" (FERREIRA, 1994, p. 90).

Em $O$ Retorno, é a diretora do hotel que encarna esse papel de falsa benemérita, disposta a ceder o seu hotel em prol da solidariedade. Contudo, rapidamente se assiste à desconstrução dessa ideia e se expõem as verdadeiras motivações daqueles que, sob falsos propósitos, saíram economicamente beneficiados devido à presença dos retornados. Adicionalmente, por razões puramente financeiras, não evitaram submetê-los a condições em tudo incompatíveis com o suposto espírito de entreajuda:

O Pacaça diz que a directora anda com cara de traseiras de tribunal mas que faz bom dinheiro à nossa custa e que ainda vai fazer mais agora que deu o andar dos hóspedes às famílias que se amontoam no aeroporto, a directora chegou à conclusão de que não há hóspedes e de que o andar vazio está a dar-lhe prejuízo, a directora diz que não é por causa do prejuízo, que é para ajudarnos, deve ser por isso que nos põe aos 
quatro e cinco num mesmo quarto e nos dá fruta podre de sobremesa. (CARDOSO, 2014, p. 107)

Ao abordar a questão dos hotéis, acabou por se contrariar a ideia de que os retornados acolhidos nos hotéis de cinco estrelas teriam tido invejadas férias de luxo. Da leitura de O Retorno, se conclui que, de todas as perdas materiais, a perda das suas casas foi a que mais abalou os retornados, pois significou ficar à mercê daqueles que, não tendo afinal motivações superiores, os obrigaram a sobreviver em condições impessoais, quando não mesmo desumanas. Destarte, os retornados viveram em hotéis, porque não tinham alternativa, porque era o teto possível, mas não a sua casa.

Fundamentalmente, o hotel representa a metáfora irónica do fim do império, da passagem do luxo à miséria, da grandiosidade à sobrevivência. As palavras de Rui exprimem desconforto perante o espaço que agora é a sua casa, um sentimento oposto ao que convencionalmente a casa significa e a que Helena Buescu se refere: "Tradicionalmente, a casa é vista como retraimento do mundo. Entrar nela, é também sair do palco social para penetrar num espaço (que seria) tendencialmente pacificador e regenerador" (1999, p. 27). De facto, não é a paz que Rui encontra quando chega 
a casa, mas o confronto com os problemas por que está a passar. No hotel, não encontra o afastamento da vida social que o espaço casa pressupõe, pois continua a ter de obedecer às convenções sociais quando, por exemplo, partilha espaços comuns, como a sala das refeições, e tem de obedecer às regras impostas pela utilização desses espaços de uso coletivo. Assim, o quarto é o espaço mais privado dentro de um empreendimento que implica o contacto e interação sociais contínuos, mas aquele quarto, agora a sua casa, é a prova da perda, da deslocalização e do desalinho das suas vidas.

A este propósito, a antropóloga Marta Vilar Rosales, no seu artigo "Retornos e recomeços: experiências construídas entre Moçambique e Portugal", considera que a perda da casa equivale "à perda de um património memorial e identitário importante, uma vez que implica a quebra da unidade de um contexto fundamental" (2017, p. 220). Com efeito, a perda da casa representou a cisão forçada com um mundo que não queriam perder, com os objetos que estimavam e que tiveram de selecionar no ato da partida, com um espaço que Ihes conferia conforto e privacidade. Assim, reféns dos limites impostos pelas dimensões de um único quarto, é a estranheza, o incómodo 
e o constrangimento que sobressaem do relato que Rui faz da primeira noite em que os três dormiram juntos pela primeira vez. Os mesmos sentimentos regressam sempre que precisa do espaço para si, mas é obrigado a dividi-lo com a mãe e com a irmã:

É a primeira vez que estamos num hotel, é a primeira vez que estamos a dormir num quarto de hotel e é também a primeira vez que estamos a dormir os três no mesmo quarto. [...]

Os três deitados, de luz apagada, ouvindo a respiração uns dos outros. A mãe e a minha irmã nas camas boas de que a directora falou e eu no divã que encostámos à parede. (CARDOSO, 2014, p. 76)

Subliminar aos desabafos que Rui vai proferindo, a par e passo, torna-se percetível o facto de a instalação em hotéis ter sido uma "solução não pensada que não serviu ninguém" nem o "meio milhão de pessoas que não tinham mais nada", como o referira numa entrevista ao jornalista Mário Crespo ${ }^{1}$. Por conseguinte, quando, passado mais de um ano, a família de Rui consegue ter a sua própria casa, ainda que esta não tenha as condições ideais, é a felicidade que define o momento por ser o primeiro passo para o regresso à normalidade: "A casa nova é um quarto e uma sala sem varanda. As janelas são

1 Entrevista concedida a Mário Crespo. Disponível em: https://www.youtube.com/ watch?v=ytQs66q6GQU\&spfreload=10. Acesso em 28 jan. 2015. 
junto ao tecto, uma nesga de luz que não alumia nada, mas a mãe está feliz como se estivéssemos a mudar-nos para um palácio" (CARDOSO, 2014, p. 238).

Em Os Pretos de Pousaflores, Aida Gomes, através das suas personagens, reencena a receção que muitos dos retornados que obtiveram o apoio da família terão tido e com a qual muitos se identificarão. Na chegada a Pousaflores, uma freguesia do concelho de Ansião, pertencente ao distrito de Leiria, no Centro de Portugal, Silvério e os filhos são recebidos pelos habitantes com a curiosidade típica dos meios pequenos e rurais. A presença de estranhos na aldeia motiva uma série de perguntas, a que Silvério responde um pouco a custo, mas os locais, reconhecendo nele um conterrâneo, acabam por validar a escolha que fez em regressar à terra, para junto dos familiares, e explicitam a sua condenação aos retornados dos hotéis, que acreditavam estar a aproveitar-se do Estado e ser a razão de tumultos maiores no futuro.

No que concerne Marcolina, irmã de Silvério, não se pode dizer que o tenha recebido propriamente de braços abertos, mas também não deixou de o acolher. A distância geográfica e temporal não despertou nela o abraço fraterno a quem nunca tinha pensado voltar a ver, mas antes a preocupação pelo sustento que estas visitas inesperadas representariam 
no seu orçamento. Paralelamente, o facto de as crianças não virem acompanhadas da mãe também não a sossega. $A$ receção de Marcolina é, pois, feita de um misto de espanto, de surpresa, de aturdimento, mas também de algum regozijo, por ver no regresso do irmão, que sempre considerou um imprestável devido às suas escolhas impulsivas, uma forma de humilhação. De assinalar, no entanto, que o torpedo dos seus pensamentos não acompanha a escassez das palavras que efetivamente profere. Neste primeiro contacto, dirige-se três vezes ao irmão: a primeira, a confirmar a sua identidade; a segunda, a evidenciar a passagem do tempo que lhe trouxe marcas físicas, mas o orgulho de nada dever a ninguém, uma tirada para ser subentendida pelo irmão; e a terceira vez, em que simplesmente diz: " - Sim, senhor!" (GOMES, 2011, p. 41), que é o que se diz quando não se quer dizer nada, não se sabe o que dizer ou não se tem nada a dizer. A verdade é que Marcolina não se negou a receber a família e com a agilidade que a caracteriza, depressa mostra a casa com o intuito de demonstrar a impossibilidade de os alojar nela. Como conta Justino, a tia podia tê-los acomodado na sala unicamente utilizada para a visita pascal anual, mas antes Ihes destina os limites exteriores da casa, o que traduzirá o transtorno que a presença inesperada da família trouxe à sua rotina e cria a distância necessária perante aqueles que, sendo da família, 
não deixavam de ser estranhos. A passagem da narrativa torna clara a melhoria nas condições de alojamento e de acolhimento, mas continua a evidenciar o peso extra que a vinda da família representou na vida de Marcolina.

Com esta personagem, Aida Gomes tornou visíveis os sentimentos controversos e contraditórios provocados pelo regresso inesperado de familiares, com os quais não se tinha qualquer contacto. Marcolina representará todos os que constituíram para os retornados uma ajuda fundamental. Porém, em Os Pretos de Pousaflores, o desenvolvimento da narrativa mostra que nem todos ajudaram a evitar o sentimento de desintegração e de infelicidade nos que chegavam de África, especialmente os filhos de Silvério. Por serem negros, sofrem os preconceitos de um país fechado sobre si mesmo, pouco habituado ao convívio multirracial, ao respeito pela diferença e à multiculturalidade. Através desse contradiscurso, Aida Gomes desconstrói a narrativa de sucesso dos retornados antes tornando evidente o sentimento de não pertença e o infortúnio destas personagens.

De resto, esse sentimento de desintegração acompanhará sempre Justino e Belmira, filhos mais velhos, obrigados pelo pai a vir para Portugal, país onde nunca se sentiram bem- 
vindos. Não obstante os esforços encetados, a certa altura, Justino, farto de ser espezinhado, decide ir para Lisboa, onde trabalha na construção civil, mas também aí se sente desintegrado e discriminado. Eventualmente, para evitar que algo de pior aconteça, regressará a Angola para procurar o irmão, uma solução que visa o reencontro com as raízes, algo que nunca conseguiu criar em Portugal. Escolhe permanecer em Angola, onde constitui família, e, à semelhança das irmãs, não mantém contacto direto e regular com o pai, o que corresponde ao cumprimento da promessa que fizera, por ter sido obrigado a vir para Portugal.

Por sofrer do mesmo sentimento de desenquadramento que motivou o irmão a partir, Belmira resolve também sair da aldeia e, já em Lisboa, sentindo-se à deriva, encontra na prostituição uma porta para a liberdade. Esse caminho leva-a ser vítima de maus-tratos por parte de alguém que, tendo exercido poder sobre os negros, durante anos, em África, quer doentiamente manter a mesma opressão em Portugal, nem que seja de forma oculta e a troco de pagamento. Contudo, a dor física não consegue sobrepor-se à sua dor psicológica e, por isso, por nunca se ter integrado, acaba por partir, à boleia de um camionista, para a Suíça, sem bagagem, mas senhora de si e do seu próprio destino, 
ao contrário do que sentira quando fora bagagem do seu pai e, por isso, submissa e sem direito a opinar.

Ercília, a filha mais nova, não tem também um percurso fácil. Tudo começa com o facto de ter sido retirada à mãe e obrigada a experienciar uma série de novidades e mudanças que a tenra idade não permite compreender. Vítima de racismo, na escola e na aldeia, acha que a decisão dos irmãos em partir é a melhor. Ainda adolescente, e depois de um namoro ingénuo e fugaz que resultou num processo de aborto, junta-se aos irmãos na Lagoa Verde e Azul. O ato, ilegal, traduz-se em perseguições policiais e em cadastro. Todavia, é desilusão que sente por nem na irmã, para junto de quem foi, encontrar o apoio de que necessitava. Regressa a Pousaflores, deprimida, e isola-se de todos, preocupando a mãe que, já mais tarde, a considera incapaz de concluir qualquer projeto. Os desaires pessoais, que não consegue ultrapassar, inibem-na de ter sucesso.

Estas três personagens negras, que nunca antes tinham estado em Portugal, constituem o exemplo de todos aqueles que, pertencendo a uma minoria no país, não foram bem acolhidos pelos portugueses, sofreram atos discriminatórios e racistas e foram impedidos de aceder, por exemplo, aos mesmos empregos que os brancos tinham. Por conseguinte, 
depreende-se que as decisões que tomam e o rumo que dão às suas vidas acabam por ser uma consequência direta das contrariedades com que tiveram de lidar e que não conseguiram ultrapassar. A sua história demonstra que o retorno e a estada forçada em Portugal foi algo que determinou a irremediabilidade das suas vidas. Até Silvério, que pertence à maioria branca, não consegue lidar com a adversidade da perda e da mudança. Para colmatar e evitar sofrimentos maiores, passa os seus dias num mundo à parte, encenando conversas com o amigo falecido e recriando situações que viveu ou que não pôde viver. Por fim, desapega-se da realidade e sobrevive à mercê dos cuidados de Deodata.

Em Caderno de Memórias Coloniais, Isabela Figueiredo também inclui episódios que nos permitem perceber que a receção e o acolhimento aos retornados nem sempre se pautaram pela cordialidade e pela correção. Aliás, é em consequência da inversão dessa postura que a autora confessa ter passado por vários estágios comportamentais, desde a aceitação e conformação com a humilhação, por sentir que era uma forma de se redimir da culpa, até à revolta, à agressividade e, finalmente, o desespero por ser espezinhada quando tinha perdido quase tudo: 
Em Portugal, habituei-me cedo a ser alvo de troça ou de ridículo, por ser retornada ou por me vestir de vermelho ou lilás. Mas o meu sentido de justiça era um pai-Nosso. Se me absolvia de culpa, eu podia atravessar, impassível, multidões de acusadores. Nada me deitava abaixo.

No entanto, o meu peito foi pactuando com o ridículo a que me expunha, e abriu-se a ele totalmente.

Vêm dizer-me que a certa altura da minha juventude eu levava tudo à frente. Era um carro de combate, uma voragem, se quiserem.

Depois, veio uma tarde em que fui obrigada a dizer a verdade: "perdi tudo excepto os meus lápis $n$ ㅇ $1^{\prime \prime}$.

Respirei fundo. E doía-me muito o peito. (FIGUEIREDO, 2011, p. 119)

Na realidade, os confrontos de que era alvo começavam em casa, no círculo familiar, de quem, por princípio, se esperaria mais condescendência, mas pelo contrário, a sua família serviu-se de uma criança desprotegida e fragilizada para arremessar acusações baseadas em ideias pré-concebidas e sem espaço a contra-argumentos. São várias as situações que traduzem esse sentimento de ser o Outro, de não pertencer ao grupo, de destoar do grupo, de não estar conforme ao expectável. A aparência, a forma de vestir, as cores vivas, 
muito usadas no seu local de origem, são fatores que despertaram em Isabela Figueiredo o sentimento de estar exposta ao desrespeito e ao ridículo.

Assim, considerando que a voz da autora representa tantas outras pessoas que vivenciaram acontecimentos similares, a sua obra torna possível a denúncia de comportamentos e atos, muitas vezes criminosos, mas calados até então, também devido à falta de condições de receção no espaço público. Por isso, e porque não é só através das obras literárias que a reflexão em torno destas problemáticas ganha terreno, é notória a participação de todas as autoras em entrevistas, depoimentos ou em colóquios e conferências de modo a ajudar a criar acolhimento sócio-literário. Ainda que, muitas vezes, o discurso proferido não dependa só da vontade das autoras por estar submisso às condições de receção, parece ser inegável o contributo destes discursos na primeira pessoa para a disseminação de outros pontos de vista acerca da mesma temática, nomeadamente através de epitextos e paratextos.

No prefácio à sexta edição do seu livro, "Palavras prévias", texto que assina na edição revista e aumentada de Caderno de Memórias Coloniais, da Caminho, a autora, seis anos após a primeira edição, dissipa qualquer dúvida quanto às suas motivações para a escrita: 
Não havia com quem falar sobre as coisas que me interpelavam, nomeadamente as que juntavam e separavam um ser humano de outro. [...] Ninguém era capaz de me explicar.

Não ter compreendido. Tudo começou aí.

É mais fácil esquecer. Sempre.

O paradoxo reside no facto de só se ultrapassarem os choques de uma vivência, desenterrando-a, revolvendo os seus restos. O tempo silencioso apenas se abstém de produzir ruído. (FIGUEIREDO, 2015, p. 8)

Embora não seja designado pela editora como prefácio, ao contrário do que acontece com os textos de José Gil e de Paulina Chiziane, ambos intitulados "Sobre Caderno de Memórias Coloniais" e que precedem o texto principal, este texto obedece às funções que Gérad Genette atribui ao prefácio - "retenir et guider le lecteur en lui expliquant pourquoi et comment il doit lire le texte" (1987, p. 220).

Na primeira edição de Caderno de Memórias Coloniais, editado pela Angelus Novus, não existe qualquer prefácio, quaisquer "palavras prévias" com o intuito de dar pistas de leitura. No entanto, no final do livro, o leitor encontra uma secção intitulada de "Adenda" e que é constituída por duas partes: "Posts" e "Sobre Isabela". "Posts" integra cinco textos do seu blogue $O$ 
Mundo Perfeito, que não foram escolhidos para o texto principal, e "Sobre Isabela" inclui uma entrevista, onde também se listam os dez livros preferidos da autora, as cinco datas e os cinco lugares, para si, mais marcantes. A inclusão desta "Adenda" terá sido uma decisão editorial estratégica com o intuito de promover o conhecimento da autora, mas ao prover o acesso a esta informação adicional, inclusive de caráter pessoal, o leitor fica elucidado relativamente ao cunho autobiográfico da obra e, inevitavelmente, estabelece ligação entre as palavras da autora e as da menina adolescente da obra.

A verdade é que, seis anos passados e cinco edições depois, munida do conhecimento que a passagem do tempo providenciou, Isabela Figueiredo sentiu necessidade de falar na primeira pessoa, de fazer uma autointerpretação da sua própria obra, de clarificar as questões que motivaram a sua rejeição do silêncio e, claro, de conduzir o leitor para uma leitura focalizada influenciando, desta forma, a sua interpretação dos factos. A partir da leitura de "Palavras prévias", percebe-se que o silêncio não pode ser, mais, o modus operandi da História, as questões universais e prementes da obra, as quais pela sua controvérsia permaneceram demasiado tempo no silêncio das memórias individuais, têm agora de ser expostas. 
A autora realça o facto de o Caderno de Memórias Coloniais a ter transportado para caminhos antes impensados e ter propiciado uma "quase psicanálise coletiva" entre aqueles que, de alguma forma se identificaram ou se reconheceram na memória dos acontecimentos. Adicionalmente, expõe as questões-chave da sua obra para se focar naquelas que Ihe parecem ainda carecer de maior explicação: o facto de a sua relação com o pai ser inabalável apesar das ideologias que os opõem e de ser absolutamente fundamental não descontextualizar a atuação do seu pai, que se revelava igual à de tantos outros: "O que ali se mostra é um homem do seu tempo, no seu contexto, tão racista como os que eram racistas, e eram muitos, na metrópole e no ultramar" (FIGUEIREDO, 2015, p. 8) As suas palavras encerram, então, o propósito maior de fazer os leitores compreenderem que a atuação do seu pai era comummente aceite à época e fundamental, pelo que todos eram coniventes com o sistema.

De todo o modo, os textos que Isabela Figueiredo começa por publicar no blogue são uma tentativa de remar contra a maré, isto é, contra aquilo que era socialmente aceite e que se encontrava já disponível nos escaparates das livrarias, cujas temáticas se dividiam entre a guerra 
colonial e o período de eldorado das colónias. Do processo de integração dos retornados, do racismo, da discriminação ou das diferenças sociais não se podia falar, como revela numa entrevista a Alexandra Prado Coelho:

Quisemos esquecer esse nosso passado, quisemos integrar-nos. Queríamos ser iguais aos outros, não queríamos ser retornados, queríamos ser portugueses. Por isso durante muito tempo não falávamos do passado e só dizíamos aquilo que era socialmente correcto. O que é que era aceitável? Participar na guerra colonial, que toda a gente está de acordo em dizer que foi má, morreu muita gente. Ou então relatos que começaram a aparecer há dois ou três anos, sobre os "fait-divers" da vida nas colónias, como era bom, tínhamos a nossa fazenda, a nossa quinta, a vida era suave e doce, tínhamos criados mas tratávamos todos os nossos criados muito bem. (FIGUEIREDO, 2009)

Em Caderno de Memórias Coloniais, Isabela Figueiredo decide tocar nas feridas e, com a voracidade que caracteriza o seu discurso, aborda temáticas controversas que implicam todos os que, hipocritamente, uma vez regressados, se isentaram da culpa e da responsabilidade e veem e falam do passado com outras lentes que não são definitivamente as suas. Através do exemplo do pai e da mãe, Isabela Figueiredo mostra que o comportamento colonialista perpetrado pela 
sua família não constituía uma exceção à regra. De facto, todos agiam da mesma forma, mas a maioria percebeu ser do seu interesse negar, ocultar ou inventar uma história distinta da real para, no seu entender, poder prosseguir caminho. A sua obra evidencia a transversalidade desses comportamentos às demais famílias brancas que contam outra versão dos factos e que merecem, por isso, a ironia e a reprovação da autora. Na tentativa de aparentarem o que não são, desconhecem até a palavra que definiu o seu comportamento durante longos anos:

Mas parece que isto era só na minha família, esses cabrões, porque segundo vim a constatar, muitos anos mais tarde, os outros brancos que lá estiveram nunca praticaram o colun..., o colonis..., o coloniamismo, ou lá o que era. Eram todos bonzinhos com os pretos, pagavam-lhes bem, tratavamnos melhor, e deixaram muitas saudades. (FIGUEIREDO, 2011, p. 49)

As obras que abordaram a temática dos retornados pretendem também contrariar a ideia, comum dos discursos anticolonialistas, de que todos aqueles que estiveram nas colónias, viveram de forma capitalista, à custa dos recursos naturais de África e da exploração do trabalho dos negros. Nelas estão representadas pessoas que partiram para as colónias, porque quiseram encontrar uma alternativa 
para a vida miserável que Portugal salazarista e rural lhes reservava e, aí, mais ou menos esforçadamente vivem do seu trabalho e têm condições económicas remediadas. No caso de Caderno de Memórias Coloniais, embora não possamos desassociar o pai de Isabela nem dos seus comportamentos agressivos e racistas nem do seu complexo de superioridade, também não nos podemos esquecer de que ele não faz parte da elite. É um eletricista que subsiste do trabalho e que dele depende para o sustento da família. No fundo, da leitura da obra se infere que há uma reprodução do modelo de violência exercido de brancos da elite sobre brancos de estatuto social inferior e a violência desses brancos, também eles oprimidos, sobre negros. Atente-se às palavras de José Gil, no prefácio a Caderno de Memórias Coloniais, da editora Caminho:

Numa colónia (dita "província ultramarina») caracterizada por uma população hegemónica de boa burguesia, sem a presença forte do "pequeno branco» como em Angola, os portugueses pobres ou modestos que emigraram não se sentiam senhores, no topo da hierarquia social. Moçambique era conhecida por albergar "a aristocracia das colónias». Um electricista branco sentia o peso dos brancos que detinham o poder real do colonialismo português. A violência aberta que o pai de Isabela exprimia, era a que ele recebia dos brancos e expulsava sobre os negros. $(2015$, p. 26) 
Em O Retorno, de Dulce Maria Cardoso, veja-se o caso ilustrativo do pai de Rui. É um homem de trabalho, agradecido por ter condições melhores do que a sua terra natal Ihe podia oferecer, mas não ganha o suficiente para, por exemplo, poder comprar, de imediato, o aspirador com que a esposa tanto sonhava:

O aspirador era um dos sonhos de que a mãe nunca se esquecia, nenhuma vizinha tinha nem queria ter um aspirador, vassoura e pá chegam bem para se limpar uma casa, vassoura, pá e uma preta, claro. Só que a mãe não queria ser uma dona de casa como as vizinhas, queria ser uma dona de casa como as do cinema, como as que tinham aspirador e aventais sem nódoas, que bebiam café sentadas em balcões altos de cozinhas imaculadas. [...] O pai prometiaIhe a cada ano que o seguinte seria o ano do aspirador mas nunca era. Se a mãe o lembrava das promessas o pai contava das letras de mais um camião que acabara de comprar, do telhado de um armazém que tinha de ser reparado, fazia contas à renda da casa, à água e à luz, à comida, aos meus estudos e aos da minha irmã, explicava o dinheiro que não chegava para tudo e a mãe adiava por mais um ano o sonho de ser uma dona de casa como as do cinema. (CARDOSO, 2014, p. 117-118)

Em Os Pretos de Pousaflores, resulta evidente a dependência de Silvério da generosidade da irmã para ter 
casa e recomeçar a sua vida. De África não trouxera riqueza, só três filhos que também precisavam de ajuda. Silvério tem, aliás, uma visão muito própria de África, porque o seu percurso é bastante distinto do das personagens de O Retorno e de Caderno de Memórias Coloniais. Em Luanda, falhadas as expectativas que tinha do contacto com os familiares, Silvério não desiste da permanência em território africano e alista-se no exército, mas essa decisão acaba por resultar em dúvidas e fá-lo pôr em causa os reais objetivos de combate:

Dois anos e três meses após [...] ali estava eu, tresmalhado nas profundezas de Angola. [...] o estômago dilacerado, o ânus em chaga, enfermo e dorido, o que me restava do espírito era uma consciência extenuada por jornadas labirínticas em território hostil. Punha-me então a pensar se não fora melhor ter aceitado a proposta de ser padeiro em Luanda. Que uma coisa era amassar o pão, cuja utilidade era clara, [...], outra era matar Mutileles. O que me parecia a posteriori não ter qualquer outra finalidade senão dar evasão à raiva que o capitão Eurico Nogueira Sotomaior sentia. (Gomes, 2011, p. 78-79)

Silvério prossegue o seu relato contando os discursos doutrinários do capitão e as suas dissertações acerca dos efeitos benéficos da missão civilizadora. Em suma, o discurso de Silvério faz perceber o vazio ideológico que ancorava a 
prossecução destas missões e o número elevado de mortes desnecessárias e infundadas que delas advieram. No fundo, os militares encontravam a sua motivação para continuar a desbravar e a matar na raiva que os dominava. À medida que o tempo passava e as condições se tornavam antagónicas, expostos à ameaça constante das doenças e da morte, os militares iam perdendo a razão.

O discurso de Silvério é, aliás, uma denúncia contínua da opressão colonizadora. Tendo vencido os Mutileles, esta personagem conta que as sentenças dos prisioneiros, escudadas em falsos preceitos morais, serviram os propósitos gananciosos colonialistas. Tratava-se, afinal, de recrutamento de mão-de-obra gratuita para proceder à exploração de diamantes, trabalhar nas plantações agrícolas ou nas obras.

O seu relacionamento com os negros, as referências constantes a Silva Porto e a curiosidade que manifesta acerca deste comerciante e explorador português, mostram o posicionamento de Silvério perante África e leva-nos a concluir que coincide com o de Silva Porto. Do seu discurso itinerante, se pode concluir que Silvério considera que Portugal nem em termos económicos beneficiou com a sua teimosia em construir e manter um império. 
Embora de Silvério seja traçada uma imagem de cafrealização, esta personagem choca não só pelos atos violentos infligidos a mulheres, que objetifica e a quem não reconhece quaisquer direitos em relação aos filhos, mas também por exercer o seu poder enquanto homem e enquanto branco. De facto, segundo Eduardo Lourenço, para um emigrante português se tornar colonialista, bastava estar em território africano. Ainda que a sua ida ou estada não tivesse sido motivada por nenhuma conviç̧ão que o colocasse numa posição superior relativamente aos negros, esse emigrante acabaria inevitavelmente por servir os interesses da pátria e ser um representante da sua missão civilizadora, tornando-se, assim, um colonialista (LOURENÇO, 2014, p. 144-145).

O caso de Deodata, a última mulher negra de Silvério, ilustra a forma como este exerce sobre ela o seu poder. Aquando da sua partida para Portugal, limita-se a comunicarIhe que se vão separar, que vai ficar sem a filha, o que a faz sentir-se enganada e coisificada, mas silencia a sua reação. Deodata sente-se "o resto", uma coisa à semelhança de outras coisas que, sendo menos importantes, não podem ser levadas para outro país. Depois de uma relação de longos anos, é abandonada no primeiro momento em que 
passou a ser considerada não uma ajuda, mas um fardo, um peso extra. No entanto, não ousa erguer a voz contra uma decisão tomada unilateralmente mesmo quando esta implica ficar sem a filha.

A forma de agir de Deodata está conforme aos princípios da sua cultura, ensinamentos de mulheres mais velhas baseados na lógica de que a mulher será sempre submissa ao homem, sob pena de ficar sozinha, e que tenta ensinar a Belmira e a Ercília e a leva a criticar Geraldina pela sua incapacidade em acatar as ordens de Silvério, mesmo padecendo de maus-tratos e estando grávida. Contudo, isso não implica que, uma vez sozinha, Deodata não tire conclusões acerca da subjugação e do sentimento de perda que os negros têm em relação aos brancos devido à opressão colonial que lhes acontece a todos os níveis.

No que respeita aos procedimentos legais, em termos do registo da filha, Deodata também não estava acautelada, pois, para todos os efeitos, Ercília só está registada com os dados do pai. Aquando do seu batismo, pelo padre da Missão, todos os espaços que implicam os laços maternais são deixados por preencher, como se Deodata não existisse ou como se não se soubesse da sua existência. Todavia, a verdade é que não havia dúvidas de que Deodata era mãe 
de Ercília, de que vivia com Silvério e com os seus dois outros filhos mulatos, de outras mães negras. Este é, assim, um sinal do menosprezo da sua existência e dos seus direitos, comum ao de tantas outras mulheres negras.

No caso da mãe de Belmira, de quem já se disse que sofria maus tratos por parte de Silvério, a guarda da filha é obtida em troca da oferta de géneros alimentícios. Geraldina é abandonada quando está grávida de Belmira e, nessa altura, Silvério parte com a promessa de a reaver e de Ihe dar uma educação. A narração do momento da entrega de Belmira é feita sob a ótica da própria Belmira e de Deodata. No relato de Deodata, continua a ser visível a sua conformação com todas as resoluções de Silvério, ainda que isso significasse cuidar de uma filha indisciplinada que não era dela. No relato de Belmira, fica evidente o sofrimento que a separação lhe provocou e como ficara marcada pela forma diferente como foi rececionada por todos os que iriam viver doravante com ela. Entre o carinho de Deodata, a curiosidade da irmã mais nova e a ausência de Justino, a falta de expressividade do pai, que a mandou chamar, é o que incomoda. É estranho que o pai seja o único a não manifestar qualquer sentimento em relação à filha que quis recuperar e que não Ihe tenha dirigido uma só palavra. Este 
comportamento poderá denotar a sua falta de sensibilidade, mas sobretudo a sua aura de poder, manifestada também neste ato de distanciamento. A mãe de Belmira constitui, então, mais um exemplo de uma separação em que a mãe negra não questiona a superioridade e o poder do pai branco, ainda por cima, tendo sido a mulher que se seguiu à mãe de Justino, Munuene, assassinada por Silvério.

O caso de Munuene é o mais grave, porque é a representação em pleno das mulheres sexualmente abusadas pelo colonizador e cujas vidas devassadas nada valem. Ao olhar do colonizador, a sua existência só tem validade enquanto objeto sexual. Munuene é uma das quatro crianças prisioneiras da última campanha contra os Mutileles e que terá sido violada por todos os homens que se quiseram aproveitar dela. Por isso, já com um filho às costas, desconhece a paternidade da criança. Munuene era, desta feita, uma escrava sexual que satisfazia os desejos de todos, uma condição que traduz a submissão completa ao poder e domínio do colonizador. Chegados a Quelingeli, como a criança tinha a pele clara, o soba escolheu Silvério para ser o pai e Munuene junta-se a ele, sem qualquer possibilidade de escolha ou contestação. Não tendo família e sendo a última descendente da sua tribo, Silvério nada oferta por ela, o 
que denota a sua falta de valor. Com Munuene partilha a vida, durante anos, reduzindo o seu papel ao cumprimento das obrigações matrimoniais inclusive sexuais. Quando engravida, Munuene começa a exibir bugigangas que jura comprar no mercado, mas Silvério desconfia que está a ser traído. Perante este cenário, é frio o suficiente para esperar que Justino nasça e para a matar, seis meses depois, de modo a pôr cobro à sua desconfiança. A sua morte fica impune e não espoleta qualquer reação por parte dos outros elementos da mesma raça, como se a morte fosse já o desfecho há muito aguardado para esta mulher. Não há manifestação de qualquer tipo de solidariedade perante esta vítima, pelo contrário, a morte de Munuene não é chorada por ninguém e propicia a relação entre Silvério e a filha do soba, Geraldina, que assim entrega a sua filha a um assassino. Também o facto de Silvério decidir partir com Justino e deixar Geraldina não origina nenhuma discussão nem implica ultrapassar nenhum obstáculo. É algo tão expectável que Silvério se permite pedir ao pai de Geraldina que tome conta da outra criança, irmão de Justino.

Os atos de Silvério são mais uma evidência de que para um homem branco tudo era possível, e ficar com os filhos representa igualmente um ato de possessão, uma 
parte de si de que não se quer abdicar. Em última análise, poderá representar a negação do colono em deixar os seus pertences ao colonizado.

Em Caderno de Memórias Coloniais, de Isabela Figueiredo, a temática da sexualidade forçada das negras também é abordada assim como o facto de os filhos não serem registados e nem sequer se saber a paternidade das crianças. Logo no segundo capítulo, Isabela Figueiredo compara a sexualidade das mulheres brancas com a das mulheres negras, fazendo uso de uma linguagem mais ousada, a transmitir o despeito que as mulheres brancas sentem por se saberem traídas pelos maridos com as mulheres negras. Estas mulheres brancas que põem o prazer sexual feminino ao nível dos instintos animais e para quem o ato sexual é só parte do cumprimento das suas obrigações matrimoniais, querem assumir uma superioridade perante as mulheres negras, da qual, na verdade, só auferem por serem brancas:

As brancas eram mulheres sérias. Que ameaça constituía para elas uma negra? Que diferença havia entre uma negra e uma coelha? Que branco perfilhava os filhos a uma negra? Como é que uma negra descalça, de teta pendurada, vinda do caniço a saber dizer, sim patrão, certo patrão, dinheiro patrão, sem bilhete de identidade, sem 
caderneta de assimilada, poderia provar que o patrão era o pai da criança.

Que preta queria levar porrada? Quantos mulatos conheciam o pai? Os brancos entravam no caniço e pagavam cerveja, tabaco ou capulana a metro à negra que Ihes apetecesse. A bem ou a mal. Depois abotoavam a braguilha e desapareceriam para as suas honestas casas de família. [...]

As incursões sexuais pelo caniço não assombravam o seu futuro, porque uma negra não tinha poder para reclamar a paternidade. Ninguém lhe daria crédito. (FIGUEIREDO, 2011, p. 14)

Com efeito, as mulheres negras não constituem qualquer ameaça para as mulheres brancas e muito menos para os homens brancos. As mulheres brancas consolam a dor da traição com a certeza de que jamais serão substituídas por elas e que os filhos que advêm destas relações não serão legalmente assumidos pelos maridos, visto que as negras não dispõem de qualquer condição que Ihes possibilite reclamar essa paternidade. São ameaçadas de "porrada" se o ousarem fazer, por isso, os seus filhos mulatos não conhecem os pais. Forçadas a manterem relações sexuais com os brancos, por medo ou em troca de comida ou dinheiro, as mulheres negras sujeitam-se às "incursões sexuais" dos homens brancos que não se coíbem de invadir 
o seu espaço e de cumprirem o seu objetivo. Então, esta é declaradamente uma relação desigual, baseada na agressão e na violação do espaço e da intimidade da mulher negra, mas desse crime não resultará qualquer julgamento ou sentença, porque constitui a norma socialmente aceite, a que a população negra se limita a obedecer. Na prática, o domínio sexual da mulher negra e a humilhação do homem negro não é mais do que um exercício de poder máximo do colonizador. Desta feita, a apropriação dos corpos negros femininos é uma amplificação da sua invasão dos territórios africanos.

Em "Corpos nus de mulheres negras: poéticas da violência / poéticas da resistência", Catarina Martins estabelece a relação simbólica entre o domínio da terra africana e o assenhoreamento das mulheres negras por parte do colonizador e refere-se à construção discursiva da corporeidade distintiva de mulheres brancas e negras, uma questão também abordada por Isabela Figueiredo. Esta diferença de perceção entre as corporalidades das mulheres negras e brancas legitima a opressão infligida sobre as mulheres negras e sobre os seus filhos quer por homens brancos quer por mulheres brancas:

Assim, a terra africana, virgem, núbil e fértil, que se oferece ao colonizador, aparece 
como o corpo feminino apropriável, sobretudo devido à exuberância selvagem e ao excesso sensual da sua Natureza. Estes atributos, por sua vez, são conferidos às mulheres negras, como Evas arquetípicas num heart of darkness que seduz inexoravelmente e ameaça, devendo, pois, ser domado. A estrita corporeidade destas fêmeas, no quadro do caos irracional dos territórios selvagens, forma o contraponto com a incorporeidade das mulheres brancas, paradoxalmente associadas a uma espiritualidade virtuosa e à pureza de Maria, mesmo na qualidade de mães. Esta oposição permite diferenciar os frutos de ventres brancos e negros, mesmo quando produto do mesmo sémen (uns, humanos; outros sub-humanos), licencia a opressão de mulheres negras por mulheres brancas, $\mathrm{e}$ responsabiliza as negras pelas sistemáticas violações. (MARTINS, 2019, p. 176)

Os companheiros negros destas mulheres negras, que mais não fazem senão resignar-se à sua condição inferior e deixarem-se violentar, limitam-se a assistir e a conformarse com as investidas que são feitas contra elas. Fazemno por medo, por subserviência e por uma questão de sobrevivência, claro. Eles são os elementos fracos numa cadeia em que o homem branco, entronado como superior, os humilha constantemente e os reduz a espectadores passivos de um ato repudiável e atentatório ao seu orgulho enquanto homens. Na opinião de Paulina Chiziane, expressa 
no prefácio à nova edição de Caderno de Memórias Coloniais, também neste aspeto, as teorias do lusotropicalismo estão subvertidas uma vez que se trata de branquear os crimes de natureza sexual perpetrados sobre as mulheres negras e de controlar os ímpetos sexuais dos homens negros. A virilidade dos homens negros constituía uma ameaça ao poder dos homens brancos que se sentiam inferiores no plano sexual e esse tipo de fragilidade não era de todo aceitável num sistema hierárquico em que o homem branco figurava no topo. Por conseguinte, a efeminação e a humilhação foram as formas usadas pelo colonizador para retirar e anular o poder do homem negro. A esta ideia, a autora acrescenta ainda a objetificação da mulher negra, não detentora de qualquer forma de poder, sempre sujeita ao domínio de homens, brancos ou negros. Quanto às mulheres brancas, que se consolam com o regresso dos maridos, como se nada se tivesse passado, a sua atitude revela também submissão, já que, na verdade elas eram as primeiras a serem subjugadas, neste sistema colonial, ou em qualquer outro, devido ao seu género. Assim, mulheres negras ou mulheres brancas são igualmente vítimas de um sistema machista que as reprime embora não ao mesmo nível (CHIZIANE, 2015).

Neste patamar de vivências oprimidas devido ao domínio masculino, as mulheres negras nunca chegam a ter voz; já 
as mulheres brancas estão limitadas a poderem exprimir as suas opiniões no círculo restrito da sua convivência com outras mulheres brancas. Juntas, descobrem na crítica às mulheres negras, que consideram inferiores, o poder que não têm nem em relação ao seu próprio corpo. Pelo menos, nesse aspeto, na medida em que assumiam explicitamente o prazer sexual, as negras estavam no mesmo patamar que os homens. Neste sentido, o controlo do corpo e o controlo das palavras determinam a obediência destas mulheres à convenção social urdida por homens e para os homens, como também o afirma Isabela Figueiredo: “Uma branca não admitia que gostasse de foder, mesmo que gostasse. E não admitir era uma garantia de seriedade para o marido, para a imaculada sociedade toda" (FIGUEIREDO, 2011, p. 21). No entender desta autora, se a mulher negra gostava do ato sexual era porque se permitia a si própria esse prazer, mas para as mulheres brancas, que eram traídas pelos maridos com mulheres negras, esse era um ato próprio dos animais e de mulheres indignas, à luz dos seus valores, por terem vários parceiros.

Os exemplos apresentados por Aida Gomes e por Isabela Figueiredo expõem o rol de atos criminosos infligidos contra os negros e contra as mulheres negras, em particular, 
que encontram cumplicidade na aceitação e no recato das suas esposas, elas próprias, moldadas pela ideologia racista e pelo sistema colonial, no qual o homem branco é quem, de facto, tem mais poder. Não se pode esquecer também que, à época, a condição de inferioridade da mulher era socialmente aceite. A discriminação de género não se colocava em causa. A mulher estava sob o domínio masculino em todos os planos e o sexual não era distinto. Por isso, o ato de possuir uma mulher é também uma forma de exercer autoridade sobre ela, de dominar um corpo que passa a ser da sua pertença e do qual tira proveito de acordo com os seus instintos sexuais.

As temáticas apresentadas, neste artigo, foram as que mereceram mais destaque à luz da perspetiva feminina embora houvesse outras que teriam também sido bastante pertinentes, por contribuírem para um conhecimento mais alargado da experiência (pós)colonial. Com efeito, o corpus eleito demonstrou grande riqueza e diversidade, pelo que a sua leitura veio ajudar a trazer para o centro das discussões vozes que ajudarão a completar os vazios da História. É neste contraponto de versões, da Literatura e da História, dos vencedores, mas sobretudos dos vencidos, que poderemos compreender melhor o passado. Não esquecendo que 
estamos a ler e a interpretar o passado no presente, esse facto não diminui a gravidade dos silêncios ou a injustiça da impunidade de todas as ações criminosas que decorreram do sistema colonial. Esse é também o contributo das mulheres escritoras para a Literatura (pós-)colonial e para a História, por possibilitar que todas as vítimas se possam rever e aprender a viver com a sua história, desta forma, esclarecida e tornada pública.

\section{REFERÊNCIAS}

ANTUNES, Maria José Lobo. Regressos Quase Perfeitos - Memórias de Guerra em Angola. Lisboa: Tinta da China, 2015.

BRANCO, Sofia. As Mulheres e a Guerra Colonial. Lisboa:. A Esfera dos Livros, 2015.

BUESCU, Helena Carvalho. A casa e a encenação do mundo. In: SILVEIRA, Jorge Fernandes. Escrever a casa portuguesa. Belo Horizonte: Editora UFMG, p. 27-47, 1999.

CARDOSO, Dulce Maria. O Retorno. Lisboa: Tinta da China, 2014.

CHIZIANE, Paulina. Sobre Caderno de Memórias Coloniais. In:

FIGUEIREDO, Isabela. Cadernos de Memórias Coloniais, Alfragide, Caminho, p. 15-22, 2015.

DULCE Maria Cardoso fala sobre "O Retorno" com Mário Crespo. João Mota. Disponível em: https://www.youtube.com/watch?v=ytQs66q6GQ U\&spfreload=10. 2012. Acesso em: 28 jan. 2015.

MARTINS, Catarina. Corpos nus de mulheres negras: poéticas da violência / poéticas da resistência. In: VEIGA, Ana Maria; NICHNIG, Claudia Regina; WOLFF, Cristina Scheibe; ZANDONÁ, Zair (Orgs.). Mundos de Mulheres no Brasil. Curitiba: Editora CRV, p. 175-184, 2019. 
EDFELDT, Chatarina. Uma história na História: Representações da autoria feminina na História da Literatura Portuguesa do século XX. Montijo: Câmara Municipal do Montijo, 2006.

FERREIRA, José Medeiros. Portugal Em Transe, História de Portugal. In: MATTOSO, José (Dir.). v. 8, Lisboa: Círculo de Leitores, 1994.

FIGUEIREDO, Isabela. Isabela Figueiredo: O colonialismo era o meu pai. [Entrevista concedida a Alexandra Prado Coelho]. Público. 23 dezembro de 2009. Disponível em: http://www.publico.pt/culturaipsilon/noticia/ isabela-figueiredo-quoto-colonialismo-era-o-meu-paiquot-247765. Acesso em 13 fev. 2016.

FIGUEIREDO, Isabela. Cadernos de Memórias Coloniais. Coimbra: Angelus Novus Editora, 2011.

FIGUEIREDO, Isabela. Cadernos de Memórias Coloniais. Alfragide: Caminho, 2015.

GENETTE, Gérard. Seuils. Paris: Éditions du Seuils, 1987.

GIL, José. Sobre Caderno de Memórias Coloniais. In: FIGUEIREDO, Isabela. Cadernos de Memórias Coloniais. Alfragide: Caminho, p. 23-28, 2015. GOMES, Aida. Os Pretos de Pousaflores. Alfragide: D. Quixote, 2011. GOMES, Carlos de Matos. Prefácio. In: BRANCO, Sofia. As Mulheres e a Guerra Colonial. Lisboa: A Esfera dos Livros, p. 9-16, 2015.

GOULD, Isabel Ferreira. Mulheres coloniais no novo romance português. Letras de Hoje. Porto Alegre, v. 42, n. 2, p. 65-74, 2007.

LOURENÇO, Eduardo. O Labirinto da Saudade. Lisboa: Gradiva, 2013.

LOURENÇO, Eduardo. Do Colonialismo como nosso impensado In: RIBEIRO, Margarida Calafate; VECCHI, Roberto (Orgs.). Lisboa: Gradiva, 2016. LUBKEMANN, Stephen C. Race, Class and Kin in the Negotiation of "Internal Strangerhood" among Portuguese Retornados, 1975-2000. In: SMITH, Andrea L. (Org.). Europe's Invisible Migrants, Amsterdam University Press, p. 75-93, 2003. Disponível em: https://www.jstor.org/ stable/pdf/j.ctt46mxq8.7.pdf?refreqid=excelsior\%3A55e1329efafc7154f 8f70944dc1383f2. Acesso em: 18 jun. 2019. 
MACHAQUEIRO, Mário. Memórias em Conflito ou o Mal-Estar de Descolonização. In: ROSAS, Fernando; MACHAQUEIRO, Mário; OLIVEIRA, Pedro (Orgs.). O Adeus ao Império. Lisboa: Nova Veja, p. 227-245, 2017. MAGALHÃES, Isabel Allegro. O sexo dos textos. Lisboa: Caminho, 1995. PIRES, Rui Pena. Migrações e Integração. Oeiras: Celta Editora, 2003. PORTUGUAL, um retrato social - Nós e os outros. António Barreto. [s/d]. Disponivel em: https://www.youtube.com/watch?v=hFykNnJg2M \&list $=P L X X m Z 21 E W J n h 1 j M i Q y \cup 09 j g a 37 t y f O G P n \& i n d e x=4$. Acesso em: 13 jun. 2015.

REIS, Bruno Cardoso. Visões das forças políticas portuguesas sobre o fim do império, dois planos em confronto e uma política exemplar de descolonização. In: ROSAS, Fernando; MACHAQUEIRO, Mário; OLIVEIRA, Pedro (Orgs.). O Adeus ao Império. Lisboa: Nova Veja, p. 78-101, 2017. ROSALES, Marta Vilar. Retornos e recomeços: experiências construídas entre Moçambique e Portugal. In: ROSAS, Fernando; MACHAQUEIRO, Mário; OLIVEIRA, Pedro (Orgs.). O Adeus ao Império. Lisboa: Nova Veja, p. 209-226, 2017.

SANTOS, António de Almeida. Quase Memórias: Do Colonialismo e da Descolonização. v. 1. Cruz Quebrada: Casa das Letras / Editorial Notícias, 2006.

SANTOS, Boaventura de Sousa. Entre Próspero e Caliban: Colonialismo, Pós-colonialismo e Identidade. In: RAMALHO, Maria Irene; RIBEIRO, António Sousa (Orgs.). Entre Ser e Estar: Raízes, Percursos e Discursos da Identidade. Porto: Edições Afrontamento, p. 23-85, 2001.

SANTOS, Maria Irene R.S.; AMARAL, Ana Luísa. Sobre a "Escrita Feminina", In: Oficina do CES. n. 90, Centro de Estudos Sociais, Coimbra. Disponível em: https://estudogeral.sib.uc.pt/bitstream/10316/10987/1/Sobre\%20 a\%20\%27Escrita\%20Feminina\%27.pdf. Acesso em: 18 nov. 2018.

\section{Sandra Isabel Marques}

Doutora em Estudos Literários, Culturais e Interartísticos, especialidade Literatura e Cultura - Estudos Comparatistas. 
Membro colaboradora do Instituto de Literatura Comparada Margarida Losa, na faculdade de Letras da Universidade do Porto.

Email: sandragmarques@gmail.com

ORCID iD: https://orcid.org/0000-0001-6537-7966 